The Canadian Mineralogist

Vol. 40, pp. 837-847 (2002)

\title{
CRYSTAL CHEMISTRY OF TETRAHEDRITE SOLID-SOLUTION: EPR AND MAGNETIC INVESTIGATIONS
}

\author{
Francesco Di BENEDETTO ${ }^{\S}$, Gian Piero BERnARDini, Daniele BORRINI and Chiara EMiLiani \\ Dipartimento di Scienze della Terra - CSMGA, Università di Firenze, via La Pira 4, I-50121 Firenze, Italy \\ Curzio CIPRIANI ANd Costanza DANTI
}

Museo di Storia Naturale, Sezione di Mineralogia, Università di Firenze, via La Pira 4, I-50121 Firenze, Italy

AndRea CANESCHI, Dante GATTESCHI and Maurizio ROMANELLI

Dipartimento di Chimica, Università di Firenze, via della Lastruccia 3, I-50019 Sesto Fiorentino, Italy

\begin{abstract}
One hundred and thirty samples from the collection of the Natural History Museum in Florence, labeled as tetrahedrite, have been extensively studied by means of SEM, XRD, EPMA, DTA, EPR and SQUID techniques. Wide-ranging substitutions, confirmed by compositional data, play a fundamental role in the thermal behavior, "stabilizing" natural tetrahedrite with respect to the synthetic equivalent. In order to determine the valence state and site occupancies of $\mathrm{Cu}$ and $\mathrm{Fe}$, electron paramagnetic resonance (EPR) and magnetic measurements were performed on selected samples of natural tetrahedrite. EPR measurements were performed down to $130 \mathrm{~K}$, and magnetic susceptibility measurements, in the range 2-300 K. EPR magnetic parameters were determined on the basis of spectral simulations. The behaviour of $\chi^{-1}$ versus temperature was interpreted by means of Heisenberg's model, thus yielding values for the Curie and Weiss constants. All samples are characterized by the presence of small amounts of $\mathrm{Cu}^{2+}$ and $\mathrm{Fe}^{2+} ; \mathrm{Fe}^{3+}$ was detected only in metal-deficient samples. Both $\mathrm{Cu}$ and $\mathrm{Fe}$ occupy the tetrahedral site; whereas in some samples the former appears aggregated in dimers, the latter is randomly distributed over the lattice. The results of the study confirm the crystal-chemical formula of the tetrahedrite samples investigated.
\end{abstract}

Keywords: tetrahedrite solid-solution, compositional data, thermal behavior, electron paramagnetic resonance, magnetic susceptibility, crystal chemistry, cupric ion.

\section{SOMMAIRE}

Nous avons caractérisé cent-trente échantillons appelés tétraédrite dans la collection du Musée d'Histoire Naturelle à Florence par microscopie électronique par balayage, diffraction X, analyse par microsonde électronique, analyse thermique différentielle, résonance paramagnétique des électrons, et la technique SQUID. Des substitutions d'étendue importante, confirmées par données chimiques, exercent un rôle fondamental dans le comportement thermique, "stabilisant" la tétraédrite naturelle par rapport à l'équivalent synthétique. Afin de déterminer la valence et la position de $\mathrm{Cu}$ et $\mathrm{Fe}$, nous avons déterminé la résonance paramagnétique des électrons (RPE) d'échantillons naturels choisis jusqu'à $130 \mathrm{~K}$, et les propriétés magnétiques sur l'intervalle 2-300 K. Les paramètres magnétiques des spectres RPE ont été déterminés par simulation. Le comportement de $\chi^{-1}$ en fonction de la température a été interpreté au moyen du modèle de Heisenberg, menant ainsi à une évaluation des constantes de Curie et de Weiss. Tous les échantillons contiennent de faibles quantités de $\mathrm{Cu}^{2+}$ et de $\mathrm{Fe}^{2+}$. En revanche, on a décelé le $\mathrm{Fe}^{3+}$ seulement dans les échantillons déficitaires en métaux. Le $\mathrm{Cu}$ et le Fe occupent le site tétraédrique. Tandis que le $\mathrm{Cu}$ semble agencé en dimères, le Fe serait plutôt distribué de façon aléatoire dans le réseau. Les résultats de notre étude confirment la formule cristallochimique des échantillons de tétraédrite étudiés.

(Traduit par la Rédaction)

Mots-clés: solution solide de la tétraédrite, données sur la composition, comportement thermique, résonance paramagnétique des électrons, susceptibilité magnétique, chimie cristalline, ion cuprique.

§E-mail address: dibenefr@geo.unifi.it 


\section{INTRODUCTION}

Tetrahedrite-group minerals, well known since antiquity, have been the object of numerous investigations from the $18^{\text {th }}$ century (Palache et al. 1944) up to modern times (e.g., Johnson et al. 1986, 1987, Makovicky \& Karup-Møller 1994, Pfitzner et al. 1997, Foit \& Ulbricht 2001, and references therein), owing to their economic importance as a source of copper and, to a lesser extent, of other elements, such as Ag. In spite of their simple fundamental structure, first illustrated by Machatschki (1928a, b), confirmed by Pauling \& Neumann (1934), assessed by Wuensch (1964) and subsequently refined for different varieties (e.g., Kalbskopf 1971, 1972, Peterson \& Miller 1986), no complete definition of their crystal chemistry has yet been achieved. Indeed, spectroscopic investigations designed to clarify some characteristics of the compositional variation and of the electronic structure (Vaughan \& Burns 1972, Johnson \& Jeanloz 1983, Jeanloz \& Johnson 1984, Vaughan \& Pattrick 1984, Pattrick et al. 1993) did not provide definitive assignments concerning the arrangement of cations in the structure. We have done an accurate chemical and thermal characterization of numerous natural samples representing different varieties, combined with electron paramagnetic resonance (EPR) and magnetic investigations, for comparisons with the sparse information avalaible for the $\mathrm{Cu}$-pure synthetic analogue, in particular on the role played by the various substituents (Makovicky \& Karup-Møller 1994, Pfitzner et al. 1997). Whereas the compositional characterization has been performed for all samples, EPR and direct magnetic measurements have been used only on selected samples. As proposed by Calas (1988) and Bernardini et al. (2000), in fact, determination of the values of the components of the magnetic tensors, g, hyperfine $\mathrm{A}$ and zero-field splitting, can give a significant contribution to knowledge of the structure of the paramagnetic site and, in particular, to the solution of problems related to the valence states and to the site occupancies of $\mathrm{Cu}^{2+}$ and $\mathrm{Fe}^{2+}$.

\section{Analytical Procedures}

One hundred and thirty samples, labeled as tetrahedrite, kindly provided by the Natural History Museum of the University of Florence, were investigated by Xray powder diffraction (XRD), electron scanning microscopy (SEM), electron-probe microanalysis (EPMA), and differential thermal analysis (DTA).

All samples were analyzed by XRD using PW 1710 diffractometer equipped with a graphite monochromator (Co tube, $20 \mathrm{~mA}, 40 \mathrm{kV}$, step size $0.01^{\circ} 2 \theta, 3 \mathrm{~s}$ per step, Si plate support), and their composition was qualitatively determined by a Philips 515 SEM equipped with an energy-dispersion specrometry (EDS) analytical system and an elaboration EDAX 9800 detector system (accelerating potential $25 \mathrm{kV}$ ). Quantitative analyses were performed using an EPMA JEOL JXA superprobe operating at $15 \mathrm{kV}$ and $10 \mathrm{nA}$ using synthetic marcasite, stibnite, sphalerite and cinnabar and pure $\mathrm{As}, \mathrm{Cu}, \mathrm{Mn}$ and $\mathrm{Ag}$ as standards. The thermal behavior of tetrahedrite-group minerals with different compositions was investigated using a Netzsch STA 409 DTA system with $5^{\circ} \mathrm{C} / \mathrm{min}$ scan rate, $\mathrm{T}=1 \mathrm{~V}$, paper speed $=10 \mathrm{~cm} / \mathrm{h}$.

Six samples (numbers 1609, 1611, 1584, 15406, 1535,47250 ) were selected for spectroscopic investigations on the basis of their different $\mathrm{Fe}: \mathrm{Zn}$ ratio. EPR measurements were performed on a Bruker 200D spectrometer equipped with ST100/700 variable-temperature assembly interfaced with Stelar software to an IBM PC computer. EPR data were collected on powders, dispersed in paraffin wax in pure amorphous silica capillaries, as reported in Bernardini et al. (2000), and the spectra were registered at the $\mathrm{X}$ band in the temperature range from 130 to $298 \mathrm{~K}$. The g-values were refined with reference to the external standard DPPH $[2,2-\mathrm{di}(4-$ tert-octylphenyl)-1-picrylhydrazyl] value $(\mathrm{g}=2.0037)$.

Magnetic susceptibilities were measured in the range 2.6-298 K with a Cryogenic S600 Superconducting QUantum Interference Device (SQUID) magnetometer at applied fields of 1 and $0.1 \mathrm{~T}$. Corrections for molecular diamagnetism, estimated from Pascal's constants (O'Connor 1981), were applied. Following the iterative Gauss-Newton method, a non-linear least-squares refinement algorithm was devised in order to refine the parameters $C_{\mathrm{x}}$ (Curie constant) and $\theta_{\mathrm{x}}$ (Weiss constant) in the Heisenberg model (Spałek et al. 1986). Convergence rate has been accelerated by means of a "shiftcutting" algorithm. For the first iteration, approximate $\mathrm{C}_{\mathrm{x}}$ and $\theta_{x}$ values, were estimated from the first-order Curie-Weiss linear model (Carlin 1986).

\section{RESULTS}

\section{Chemical composition}

The formula coefficients of the analyzed samples recalculated from EPMA data on the basis of thirteen atoms of sulfur are reported in Table 1. The Hg content ranges from traces to 1.65 atoms per formula unit, $a p f u$, whereas $\mathrm{Mn}$, the content of which is invariably lower than that reported in the literature (Basu et al. 1984, Dobbe 1992), is not coupled with $\mathrm{Cd}$ or $\mathrm{Pb}$. The analytical data confirm the complete substitution between $\mathrm{Sb}$ and $\mathrm{As}, \mathrm{Cu}$ and $\mathrm{Ag}$ and $\mathrm{Fe}$ and $\mathrm{Zn}$, in agreement with the data of Johnson et al. (1987) and Foit \& Ulbricht (2001); no relationship between the $\mathrm{Cu}$ or $\mathrm{Fe}$ and As was detected, in disagreement with the results of Charlat \& Lévy (1974).

The triangular diagram (Fig. 1) confirms not only the substitution involving $\mathrm{Cu}$ and $\mathrm{Ag}$ but also, where the sum $\mathrm{Cu}+\mathrm{Ag}$ is higher than $10 a p f u$, that between $\mathrm{Cu}$ and the sum $\mathrm{Fe}+\mathrm{Zn}+\mathrm{Hg}$, pointing to the presence of $\mathrm{Cu}^{2+}$, as proposed by some authors (Foit \& Ulbricht 2001, and references therein). The existence of metal- 
TABLE 1. FORMULA COEFFICIENTS $(S=13)$ OF THE TETRAHEDRITE SAMPLES ANALYZED*

\begin{tabular}{|c|c|c|c|c|c|c|c|c|c|c|c|c|c|c|c|c|c|}
\hline Sample & $\mathrm{Cu}$ & $\mathrm{Ag}$ & $\mathrm{Fe}$ & $\mathrm{Zn}$ & $\mathrm{Mn}$ & $\mathrm{Hg}$ & $\mathrm{Sb}$ & As & Sample & $\mathrm{Cu}$ & Ag & $\mathrm{Fe}$ & $\mathrm{Zn}$ & Mn & $\mathrm{Hg}$ & $\mathrm{Sb}$ & As \\
\hline $\begin{array}{l}1063 \text { apfu } \\
1500\end{array}$ & $\begin{array}{r}9.93 \\
10.82\end{array}$ & 0.27 & $\begin{array}{l}0.35 \\
1.07\end{array}$ & 1.68 & 0.05 & & 2.99 & $\begin{array}{l}0.85 \\
3.56\end{array}$ & 1573 apfu & $\begin{array}{l}9.97 \\
9.57\end{array}$ & $\begin{array}{l}0.18 \\
0.14\end{array}$ & $\begin{array}{l}0.12 \\
0.58\end{array}$ & $\begin{array}{l}1.99 \\
1.32\end{array}$ & 0.06 & & $\begin{array}{l}3.50 \\
1.05\end{array}$ & $\begin{array}{l}0.53 \\
2.69\end{array}$ \\
\hline 1506 & 10.27 & 0.04 & 1.64 & 0.33 & & & 1.05 & 2.92 & 1574 & 9.70 & 0.36 & 0.18 & 1.84 & & & 3.11 & 0.94 \\
\hline 1500 & 10.27 & 0.08 & 1.46 & 0.51 & & & 2.01 & 1.97 & 1575 & 8.12 & 2.03 & 0.13 & 1.96 & & & 2.75 & 0.32 \\
\hline 1508 & 7.86 & 2.28 & 1.13 & 0.85 & & & 3.91 & 0.09 & 1576 & 8.76 & 1,30 & 0.19 & 1.79 & & & 3.64 & 0.40 \\
\hline 1510 & 9.90 & & 1.34 & 0.23 & & 0.21 & 2.94 & 0.83 & 1577 & 8.75 & 1.35 & 0.19 & 1.82 & & & 3.61 & 0.39 \\
\hline 1511 & 9.96 & & 1.08 & 0.09 & & & 2.98 & 0.81 & 1578 & 8.03 & 1.93 & 0.23 & 1.70 & & & 3.76 & 0.27 \\
\hline 1513 & 9.54 & & 1.11 & & & & 1.96 & 1.93 & 1579 & 8.58 & 1.41 & 0.18 & 1.81 & & & 3.69 & 0.32 \\
\hline 1516 & 10.27 & 0.03 & 0.70 & 1.03 & & 0.29 & 3.21 & 0.86 & 1580 & 10.07 & 0.07 & 0.34 & 1.59 & & & 3.07 & 0.84 \\
\hline 1521 & 9.91 & 0.08 & 0.27 & 1.78 & & & 3.98 & 0.03 & 1581 & 8.26 & 1.01 & 0.17 & 1.61 & & & 3.75 & 0.25 \\
\hline 1522 & 9.73 & 0.30 & 0.89 & 1.14 & & & 3.61 & 0.34 & 1582 & 7.39 & 2.73 & 0.82 & 0.84 & & 0.31 & 3.81 & 0.25 \\
\hline 1525 & 9.75 & 0.16 & 1.39 & 0.15 & & 0.20 & 3.97 & 0.09 & 1583 & 9.77 & 0.31 & 0.20 & 1.77 & 0.05 & & 3.55 & 0.48 \\
\hline 1527 & 9.25 & 1.44 & 0.31 & 1.60 & & & 3.50 & 0.16 & 1584 & 10.32 & 0.01 & 1.41 & 0.31 & & & 2.24 & 1.64 \\
\hline 1532 & 4.32 & 6.68 & 1.83 & 0.40 & & & 4.42 & & 1585 & 9.75 & 0.25 & 0.38 & 1.57 & & & 3.57 & 0.44 \\
\hline 1533 & 9.85 & 0.08 & 0.92 & 1.19 & & & 2.11 & 1.81 & 1586 & 9.89 & 0.15 & 0.13 & 1.85 & & & 3.55 & 0.45 \\
\hline 1534 & 9.98 & & 0.73 & 1.02 & & 0.09 & 1.98 & 1.86 & 1588 & 10.37 & 0.03 & 1.29 & 0.30 & & & 2.58 & 1.24 \\
\hline 1535 & 9.92 & & 1.03 & 0.35 & & & 2.36 & 1.53 & 1589 & 9.81 & 0.05 & 0.04 & 0.34 & & 1.55 & 3.16 & 0.73 \\
\hline 1536 & 7.08 & 3.12 & 0.77 & 1.30 & & & 2.53 & 1.24 & 1590 & 9.11 & & & 0.33 & & 1.53 & 3.04 & 0.80 \\
\hline 1537 & 9.92 & 0.19 & 1.43 & 0.14 & & & 3.96 & 0.11 & 1591 & 10.39 & 0.13 & 1.46 & 0.41 & & & 3.51 & 0.58 \\
\hline 1539 & 10.52 & & 1.26 & 0.22 & & & 2.75 & 1.24 & 1592 & 10.53 & & 1.22 & 0.27 & & & 2.64 & 1.27 \\
\hline 1542 & 9.76 & 0.18 & 1.32 & 0.67 & & & 3.63 & 0.29 & 1593 & 10.18 & 0.08 & 0.96 & 0.44 & & 0.22 & 2.27 & 1.65 \\
\hline 1543 & 10.03 & 0.16 & 1.35 & 0.68 & & & 3.69 & 0.38 & 1594 & 8.95 & 0.99 & 1.71 & 0.22 & & 0.03 & 3.88 & 0.13 \\
\hline 1544 & 9.88 & 0.16 & 0.89 & 1.07 & & & 2.77 & 1.16 & 1595 & 10.35 & & 1.19 & 0.40 & & & 2.27 & 1.65 \\
\hline 1545 & 10.17 & & 1.60 & 0.29 & & 0.05 & 2.70 & 1.23 & 1596 & 9.63 & 0.19 & 1.58 & 0.17 & & 0.21 & 3.87 & 0.12 \\
\hline 1546 & 6.81 & 3.42 & 1.65 & & & & 3.64 & 0.41 & 1597 & 9.82 & 0.19 & 1.60 & 0.17 & & 0.21 & 3.88 & 0.11 \\
\hline 1547 & 8.83 & 0.32 & 0.41 & 1.23 & & & 3.77 & 0.21 & 1600 & 10.05 & 0.03 & 0.79 & 1.00 & & 0.03 & 1.92 & 1.95 \\
\hline 1548 & 9.64 & 0.25 & & 2.01 & & & 3.85 & & 1601 & 10.08 & 0.03 & 0.54 & 1.37 & & 0.03 & 1.91 & 1.97 \\
\hline 1550 & 9.02 & 0.71 & & 0.27 & & 1.65 & 3.28 & 0.56 & $160 ?$ & 9.41 & & 1.92 & 0.25 & & & 1.04 & 2.73 \\
\hline 1551 & 9.92 & & 1.62 & 0.28 & & & 2.76 & 1.15 & 1602 & 8.69 & & 1.78 & 0.50 & & & 3.27 & 0.40 \\
\hline 1552 & 9.98 & 0.06 & 0.85 & 0.97 & & 0.06 & 1.87 & 2.01 & 1605 & 9.81 & 0.02 & 1.50 & 0.59 & & & 3.83 & 0.17 \\
\hline 1553 & 9.67 & 0.20 & 0.15 & 1.89 & & & 3.70 & 0.34 & 1606 & 9.93 & 0.51 & 0.30 & 1.73 & & & 4.07 & 0.06 \\
\hline 1554 & 10.19 & 0.00 & 0.40 & 1.58 & & 0.10 & 3.98 & 0.06 & 1607 & 8.28 & 1.49 & 0.27 & 1.73 & & & 3.77 & 0.23 \\
\hline 1556 & 9.99 & 0.15 & 0.97 & 0.79 & & & 3.49 & 0.51 & 1609 & 10.07 & 0.08 & 0.68 & 1.07 & & 0.07 & 2.29 & 1.58 \\
\hline 1559 & 9.89 & 0.12 & 0.18 & 1.88 & & & 3.13 & 0.80 & 1611 & 10.28 & 0.06 & 0.87 & 0.88 & & 0.05 & 2.00 & 1.98 \\
\hline 1562 & 9.90 & 0.20 & 0.17 & 1.87 & & & 3.52 & 0.39 & $161 ?$ & 9.84 & 0.14 & 0.76 & 1.14 & & & 2.25 & 1.64 \\
\hline 1563 & 9.63 & 0.13 & 0.16 & 1.90 & & & 3.36 & 0.64 & 1612 & 9.71 & 0.22 & 0.25 & 1.68 & & & 3.70 & 0.27 \\
\hline 1564 & 9.06 & 0.80 & 0.24 & 1.57 & 0.25 & & 3.66 & 0.38 & 2122 & 9.69 & 0.27 & 1.23 & 0.83 & & & 3.91 & 0.16 \\
\hline 1565 & 9.79 & 0.11 & 0.10 & 2.38 & & & 3.59 & 0.44 & 14196 & 9.85 & 0.08 & 0.49 & 1.49 & & & 2.74 & 1.26 \\
\hline 1567 & 8.01 & 2,01 & 0.27 & 1.79 & & & 3.73 & 0.23 & 14967 & 9.83 & 0.15 & 0.64 & 1.42 & & & 3.30 & \\
\hline 1568 & 9.99 & 0.06 & 0.68 & 1.33 & & & 3.15 & 0.82 & 15313 & 10.04 & & & 1.66 & & 0.31 & 3.46 & 0.53 \\
\hline 1570 & 10.12 & & 0.20 & 1.93 & & & 3.87 & 0.02 & 15406 & 10.13 & 0.08 & 0.37 & 1.41 & & 0.18 & 3.68 & 0.32 \\
\hline 1571 & 10.08 & 0.03 & 0.13 & 1.64 & 0.16 & & 0.17 & 3.58 & 15859 & 9.82 & & 1.45 & 0.63 & & & 3.87 & 0.16 \\
\hline 1311 & 10.19 & 0.10 & 1.01 & 0.77 & 0.09 & & 1.00 & 2.81 & 15863 & 10.05 & 0.04 & 0.33 & 1.47 & & 0.14 & 3.73 & 0.41 \\
\hline 1572 & 8.38 & 1.59 & 0.19 & 1.80 & 0.02 & & 3.69 & 0.28 & 47250 & 10.43 & & 0.36 & 1.65 & & & 0.52 & 3.25 \\
\hline
\end{tabular}

* Electron-microprobe data.

poor samples (metal sum less than 12 apfu), reported in Table 2, supports the hypothesis of the presence of $\mathrm{Cu}^{2+}$ or $\mathrm{Fe}^{3+}$, or both, as suggested by Foit \& Ulbricht (2001). In these metal-poor samples, the possible presence of $\mathrm{Fe}^{3+}$ does not seem to be correlated with the total $\mathrm{Fe}$ content, as reported by Makovicky et al. (1991).

\section{$X$-ray diffraction}

The $a$ cell edge of the tetrahedrite samples tends to increase with increasing $\mathrm{Sb}$ content and with decreasing $\mathrm{Cu}$ content (Foit \& Ulbricht 2001). The effect of other substituents does not seem to lead to definite trends, as already observed by Charlat \& Lévy (1974), thus suggesting their possible averaging roles. The overall contribution of the substituents on $a$ value has been estimated by Johnson et al. (1987) in terms of the following expression:

$$
\begin{aligned}
& a_{\text {pred }}=10.379+0.082(\mathrm{Ag})-0.01\left(\mathrm{Ag}^{2}\right) \\
& -0.09\left(\mathrm{Cu}^{*}\right)-0.066(\mathrm{Hg})-0.038(\mathrm{As})-0.144(\mathrm{Bi}), \\
& \text { where } \mathrm{Cu}^{*}=2-(\mathrm{Fe}+\mathrm{Zn}+\mathrm{Hg}+\mathrm{Cd}) .
\end{aligned}
$$

The $a_{\text {pred }}$ values calculated on the basis of the collected compositional data fit well the observed ones with a mean residual value $|0.028| \AA$ (Fig. 2).

The poor correlations observed for $a$ versus $\mathrm{Sb}$ and a versus $\mathrm{Cu}$ could be accounted for by considering these samples to show split X-ray-diffraction peaks, which may be due to coexisting tetrahedrite-group phases with very small compositional differences. In fact, considering only the $\mathrm{Cu}$-rich and $\mathrm{Cu}$-poor synthetic compounds, Tatsuka \& Morimoto (1977a) suggested the presence, at low temperature, of coexisting tetrahedrite and "pseudotetrahedrite", as named by the authors, the diffraction patterns of which differ only by the presence of some "superstructure" reflections. The small number of Ag-rich samples has not allowed us to study the relative $a_{\text {pred }}$ trend as suggested by Pattrick \& Hall (1983).

\section{Thermal behavior}

The DTA spectra, run on about 20 out of the 130 samples characterized, show various features that allow us to group their relative curves in four categories, 
uncorrelated with specific composition (Fig. 3). In Figure 4, the DTA curve of the pure $\mathrm{Cu}$ synthetic analogue, used as standard, is reported. That curve shows three

TABLE 2. FORMULA COEFFICIENTS OF METAL-POOR TETRAHEDRITE

\begin{tabular}{|c|c|c|c|c|c|c|}
\hline sample & $\mathrm{Cu}$ & $\mathrm{Ag}$ & $\mathrm{Fe}$ & $\mathrm{Zn}$ & $\mathrm{Hg}$ & $\Sigma$ metals \\
\hline $\begin{array}{l}1511 \text { apfu } \\
1513 \\
1535 \\
1581 \\
1590\end{array}$ & $\begin{array}{l}9.96 \\
9.54 \\
9.92 \\
8.26 \\
9.11\end{array}$ & $\begin{array}{l}- \\
- \\
1.01 \\
-\end{array}$ & $\begin{array}{l}1.08 \\
1.11 \\
1.03 \\
0.17 \\
-\end{array}$ & $\begin{array}{l}0.09 \\
-.35 \\
0.35 \\
.61 \\
0.33\end{array}$ & $\begin{array}{l}- \\
\vdots \\
i .53\end{array}$ & $\begin{array}{l}11.13 \\
10.65 \\
11.30 \\
11.05 \\
10.97\end{array}$ \\
\hline
\end{tabular}

The coefficients are calculated on the basis of $13 \mathrm{~S}$ atoms per formula unit (apfu).

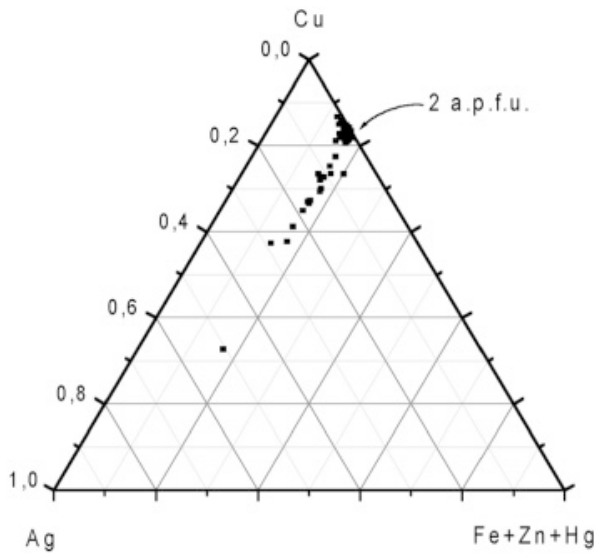

FIG. 1. Ternary diagram of EPMA data.
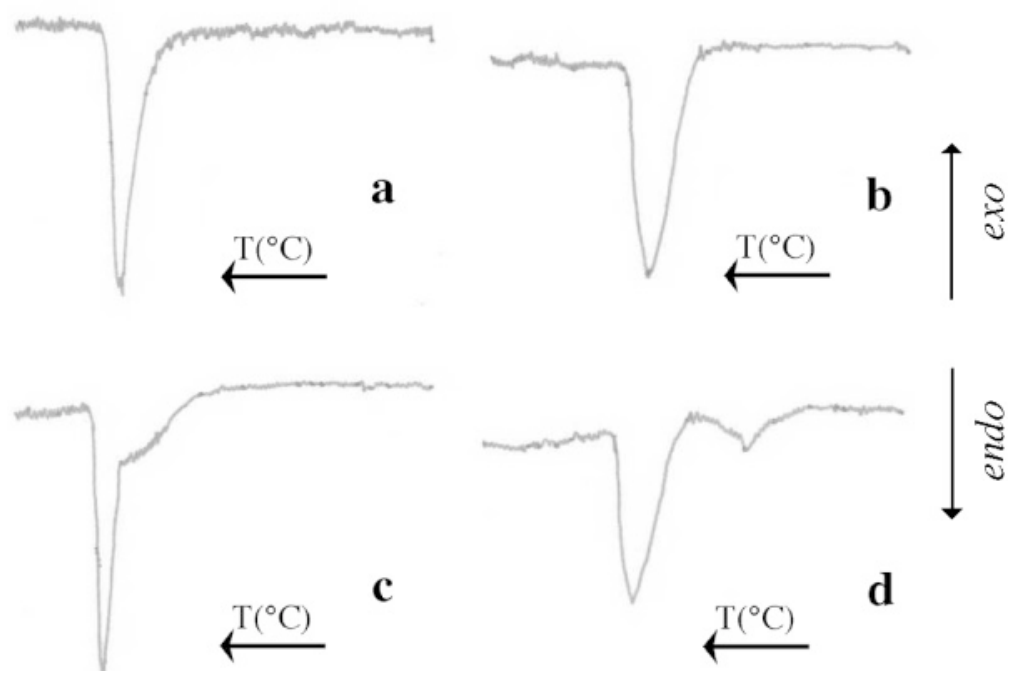

endothermic effects beginning at a temperature close to $540^{\circ}, 580^{\circ}$ and $600^{\circ} \mathrm{C}$, respectively. The first effect may be ascribed to the decomposition process suggested by Skinner et al. (1972) who, however, did not publish their DTA curve. The other two effects should correspond to the incongruent melting of the breakdown products, i.e., famatinite, skinnerite and high digenite. In their study on the role of the $\mathrm{Fe}$ content in stabilizing breakdown products of the $\mathrm{Cu}$-pure synthetic tetrahedrite, Tatsuka \& Morimoto (1977b) reported only the high-temperature part of their DTA runs, thus not showing whether any endotermic effect developed before the $695-720^{\circ} \mathrm{C}$ high-temperature peaks.

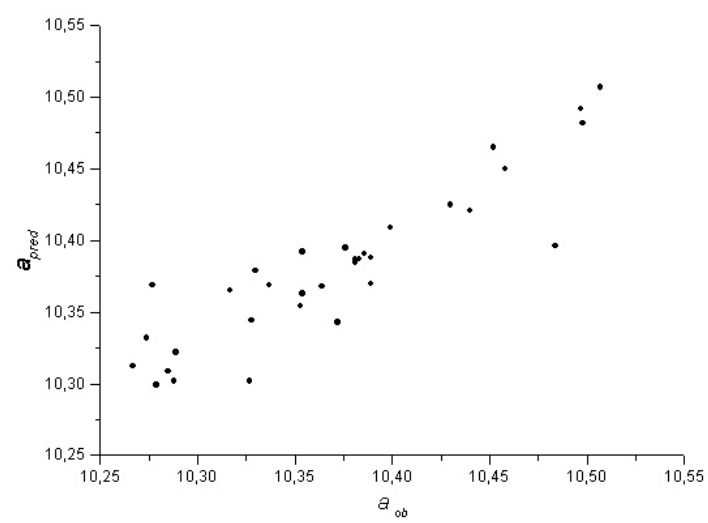

FIG. 2. Correlation between predicted $a\left(a_{\text {pred }}\right)$ and $a$ obtained from XRD spectra $\left(a_{o b}\right)$.

FIG. 3. DTA curves of natural samples, temperature range $500^{\circ}-800^{\circ} \mathrm{C}\left(5^{\circ} \mathrm{C} / \mathrm{min}\right)$. 
Comparing the DTA curves of the natural samples of tetrahedrite run in this study with that of the pure-Cu synthetic compound, a role similar to that played by $\mathrm{Fe}$ may be assigned to $\mathrm{Zn}$, as proved by the single thermal effect (detected both on heating and on cooling) beginning at $695^{\circ} \mathrm{C}$ for sample 1562 , characterized by a very high $\mathrm{Zn}$ content (Fig. 3a). The DTA curves of the other three categories of tetrahedrite show, respectively: a large and asymmetrical peak at $655^{\circ} \mathrm{C}$ (category b), a peak with a shoulder beginning at $665^{\circ} \mathrm{C}$ (category c), and two peaks beginning at $595^{\circ}$ and $660^{\circ} \mathrm{C}$ (category d). These features may be ascribed to an incongruent melting process. The different morphologies of these three DTA patterns may be explained by a binary peritectic-type reaction which, obviously, cannot be directly applied to compositionally complicated natural compounds, but the quenching experiments performed on sample 1588 , from different temperatures $\left(800^{\circ}\right.$ and $500^{\circ} \mathrm{C}$ ), confirm the possibility of such a reaction. The microphotographs of the associations revealed in the products quenched from $800^{\circ}$ and from $500^{\circ} \mathrm{C}$ and in the final product of the DTA are shown in Figure 5. In Figure 5a, an Iss-type solid enclosed in a Sb-rich quenched melt is observed, whereas in Figure 5b, the crystallization of a tetrahedrite-type material, due to the reaction between the Iss solid phase and the Sb-rich melt, is evident. Finally, the crystallization of a chalcostibite-type material from the residual melt clearly appears in Figure 5c. According to the different composition of the starting materials (e.g., more Fe- or $\mathrm{Zn}$-rich and with different percentage of minor elements), different phases (e.g., chalcopyrite, bornite) may crystallize from the residual melt, in agreement with the observation of Tatsuka \& Morimoto (1977b).

\section{Electron paramagnetic resonance}

The EPR spectra of the six selected samples, registered at different temperatures from 130 to $298 \mathrm{~K}$, are plotted as the first derivative of microwave absorption (Figs. 6-9) with respect to the applied Zeeman magnetic field. A signal at about $3300 \mathrm{G}$ is present in all spectra. The line shapes of the samples, except 1609, do not al- low for resolution of the hyperfine structure; changes in the line position and in the line shape characterize the spectra registered below room temperature. Line position and shape may be attributed to $\mathrm{Cu}^{2+}$ paramagnetic centers; the experimental average g-value ( 2.07) is in agreement with the range proposed by Peisach \& Blumberg (1974) for $\mathrm{Cu}^{2+}$ in sulfide systems. Moreover, both line shapes and positions are similar to those presented for $\mathrm{Cu}^{2+}$ in sulfide minerals (Bente 1987, Bernardini et al. 2000). The broadness of the line is probably due to spin-spin interactions, between spins belonging to different paramagnetic centers, i.e., between $\mathrm{Cu}^{2+}$ and $\mathrm{Fe}^{2+}$ ions, the latter being undetectable at the EPR X-band.

The very similar EPR spectra of samples 1584 and 15406 (Fig. 6) are characterized by the low intensity of the absorption band. By lowering the temperature, the line width decreases, even if its shape remains asymmetrical. In sample 1535 (Fig. 7), the main absorption is characterized by two lines at $\sim 3200$ and $\sim 2800 \mathrm{G}$; the line shape, almost unchanged down to $160 \mathrm{~K}$, shows a drastic variation at $130 \mathrm{~K}$. Two more lines are invariably present: the first is centered at $\sim 1600 \mathrm{G}$, and its position and shape can be attributed to small amounts of $\mathrm{Fe}^{3+}$ (in agreement with the chemical data reported in Table 2). The second, extremely narrow and centered at $\sim 3400 \mathrm{G}$, is due to the resonant field of a free electron, $g \approx 2$ (Abragam \& Bleaney 1970). By decreasing temperature, both lines show a gradual variation in shape; the former narrows and the latter increases in intensity. A detailed study of the signal due to "free electrons", related to the conductivity of the material, will be reported in a forthcoming paper concerning the synthetic analogue of tetrahedrite, $\mathrm{Cu}_{12} \mathrm{Sb}_{4} \mathrm{~S}_{13}$. Samples 1609 and 47250 (Fig. 8) have similar spectra at room temperature, except for the almost resolved hyperfine structure of the former. The two samples also show a similar behavior with temperature down to $160 \mathrm{~K}$, but at $130 \mathrm{~K}$ both spectra clearly change, differing from each other. Spectra for sample 1611 (Fig. 9) are characterized by one line with a great intensity, centered at $\sim 3200$ $\mathrm{G}$, which does not show the presence of a hyperfine structure. Variations of the line shape are evident at all temperatures.

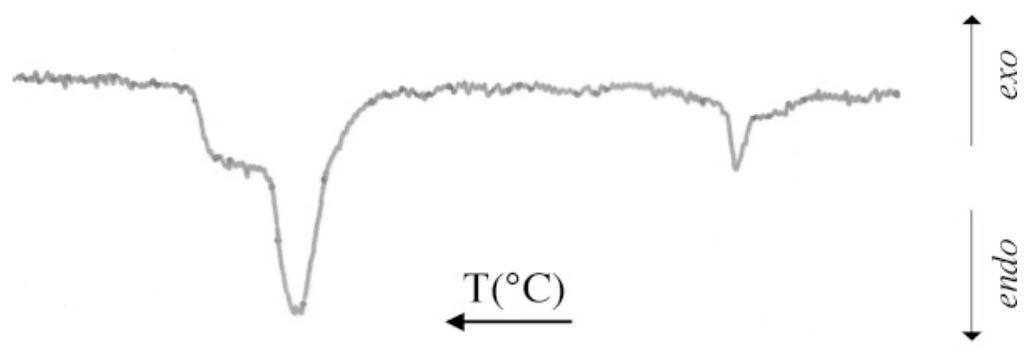

FIG. 4. DTA curve of synthetic tetrahedrite, temperature range $500^{\circ}-800^{\circ} \mathrm{C}\left(1^{\circ} \mathrm{C} / \mathrm{min}\right)$. 
Simulations of the spectra, necessary for a more accurate determination of the magnetic parameters, were performed by means of SimFonia, part of the WINEPR package provided by Bruker Analytische Messtechnik $\mathrm{GmbH}$. In this software, the spin Hamiltonian is treated by using the second-order perturbation theory. In order to obtain a good fit of the experimental spectra, it was necessary to consider the zero-field-splitting (ZFS) parameters for all samples, except 1584 and 15406, the spectra of which are very similar to those of synthetic stannite (Bernardini et al. 2000). The introduction of ZFS parameters implies the presence of dimers of $\mathrm{Cu}^{2+}$, where the exchange interaction presents an anisotropic character (Abragam \& Bleaney 1970). Best-fit parameters are reported in Table 3.

The spectra of samples 1584 and 15406 can be explained by the presence of a small fraction of paramagnetic $\mathrm{Cu}^{2+}$, the signal of which is only slightly broadened by the surrounding $\mathrm{Fe}$ atoms. The magnetic parameters suggest the presence of isolated $\mathrm{Cu}^{2+}$ in the tetrahedra, in agreement with the findings of Bernardini et al. (2000). The spectral changes, which appear upon low- ering the temperature, suggest the presence either of two competitive sites of $\mathrm{Cu}^{2+}$, i.e., two slightly different distortions of the tetrahedral coordination, or of a transition of $\mathrm{Cu}^{2+}$ between the two different arrangements. In all other samples, the values for ZFS magnetic parameters (D and E) suggest the presence of an anisotropic exchange-interaction (Abragam \& Bleaney 1970). $\mathrm{Cu}^{2+}$ dimers display similar ZFS values. A variation of gvalues at low temperature $(130 \mathrm{~K})$ in sample 47250 , 1609 and 1535 suggests a structural rearrangement of the site coordination. ZFS parameters are smaller in 1611 than in samples 1535, 1609 and 47250, and g-tensor values indicate a quasi-axial symmetry. In sample 1611, a greater amount of $\mathrm{Cu}^{2+}$ might be responsible for the higher intensity of its spectra. The good agreement between experimental spectra and those simulated with the parameters shown indicates that clusters of higher size are negligible, if any are present.

Two structural models of possible dimers of $\mathrm{Cu}^{2+}$ are shown in Figure 10a and b, the first constituted by two adjacent ("cis") positions of the octahedron formed by joining $M_{2}$ sites around $\mathrm{S}_{2}$, and the second consti-
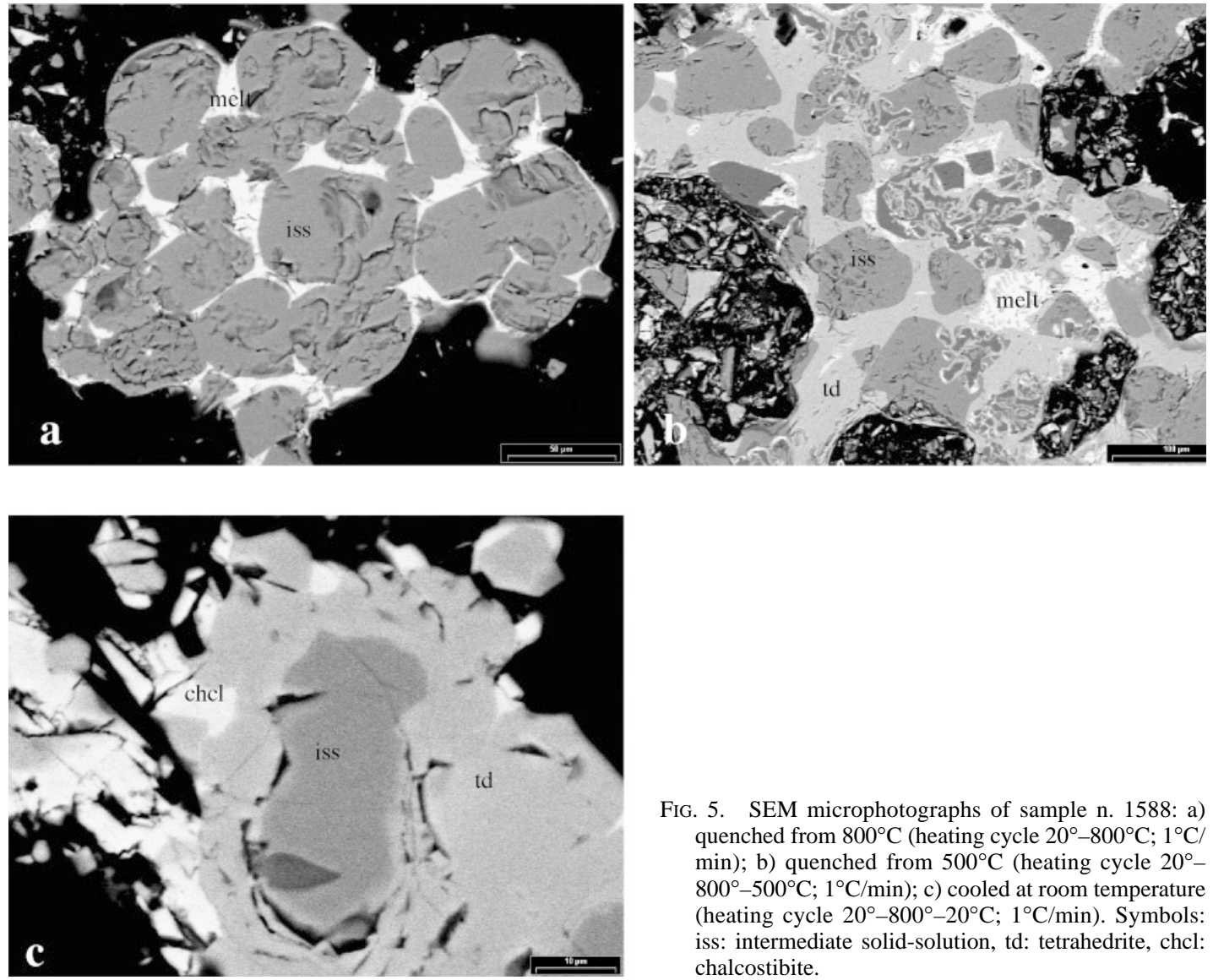

FIG. 5. SEM microphotographs of sample n. 1588: a) quenched from $800^{\circ} \mathrm{C}$ (heating cycle $20^{\circ}-800^{\circ} \mathrm{C} ; 1^{\circ} \mathrm{C} /$ min); b) quenched from $500^{\circ} \mathrm{C}$ (heating cycle $20^{\circ}-$ $\left.800^{\circ}-500^{\circ} \mathrm{C} ; 1^{\circ} \mathrm{C} / \mathrm{min}\right)$; c) cooled at room temperature (heating cycle $20^{\circ}-800^{\circ}-20^{\circ} \mathrm{C} ; 1^{\circ} \mathrm{C} / \mathrm{min}$ ). Symbols: iss: intermediate solid-solution, td: tetrahedrite, chcl: chalcostibite. 


\begin{tabular}{|c|c|c|c|c|c|c|c|c|c|c|c|c|c|}
\hline & $\mathrm{T}(\mathrm{K})$ & $\mathbf{g}_{1}$ & $\mathrm{~g}_{2}$ & $\mathrm{~g}_{3}$ & $a_{1}$ & $a_{2}$ & $a_{3}$ & $\Delta \mathrm{H}_{1}$ & $\Delta \mathrm{H}_{2}$ & $\Delta \mathrm{H}_{3}$ & D & $\mathrm{E}$ & $J_{i=0}$ \\
\hline 1584 & 298 & 2 & 2.07 & 2.7 & 200 & 15 & 300 & 250 & 350 & 400 & 1 & 1 & 1 \\
\hline (15406) & 130 & 2 & 2.07 & 2.7 & 280 & 15 & 300 & 230 & 35 & 200 & 1 & 1 & 1 \\
\hline \multirow[t]{2}{*}{1535} & 298 & 1.85 & 2.07 & 2.6 & 130 & 5 & 80 & 130 & 100 & 70 & -170 & 0 & 0.752 \\
\hline & 130 & 1.8 & 2.1 & 3 & 140 & 5 & 40 & 260 & 100 & 250 & -160 & 20 & 0.251 \\
\hline \multirow[t]{2}{*}{47250} & 298 & 1.9 & 2.03 & 2.67 & 360 & 35 & 160 & 230 & 50 & 280 & -250 & 0 & 0.854 \\
\hline & 130 & 1.8 & 2.1 & 3 & 130 & 30 & 100 & 90 & 80 & 120 & -110 & 0 & 0.167 \\
\hline \multirow[t]{2}{*}{1609} & 298 & 2.03 & 2.09 & 2.7 & 310 & 15 & 170 & 140 & 140 & 200 & -290 & 0 & 0.924 \\
\hline & 130 & 1.9 & 2.03 & 2.7 & 250 & 5 & 80 & 110 & 80 & 160 & -120 & 0 & 0.372 \\
\hline \multirow[t]{2}{*}{1611} & 250 & 2.14 & 2.13 & 2.4 & 70 & 0 & 80 & 100 & 80 & 120 & -160 & 0 & 2.730 \\
\hline & 130 & 2.15 & 2.13 & 2.5 & 70 & 0 & 80 & 100 & 80 & 120 & -120 & 0 & 1.074 \\
\hline
\end{tabular}

$\mathrm{g}_{1}, \mathrm{~g}_{2}$, and $\mathrm{g}_{3}$ are the values of the $\mathrm{g}$-tensor; $\mathrm{a}_{1}, \mathrm{a}_{2}, \mathrm{a}_{3}$ are the values of the hyperfine $\mathrm{g}_{1}, \mathrm{~g}_{2}$, and $\mathrm{g}_{3}$ are the values of the $\mathrm{g}$-tensor; $\mathrm{a}_{1}, \mathrm{a}_{2}, \mathrm{a}_{3}$ are the values of the hyperfine tensor (in $\mathrm{G}$ ). $\Delta \mathrm{H}_{1}, \Delta \mathrm{H}_{2}, \Delta \mathrm{H}_{3}$ are the values of gaussian linewidth (in $\mathrm{G}$ ). $\mathrm{D}$ and $\mathrm{E}$
are the values of the $\mathrm{ZFS}$ tensor (in $\mathrm{G}$ ). $\mathrm{J}_{\text {inco }}$ values, expressed in $\mathrm{cm}^{-1}$, were obtained from $D$ values by the formula reported in the text.

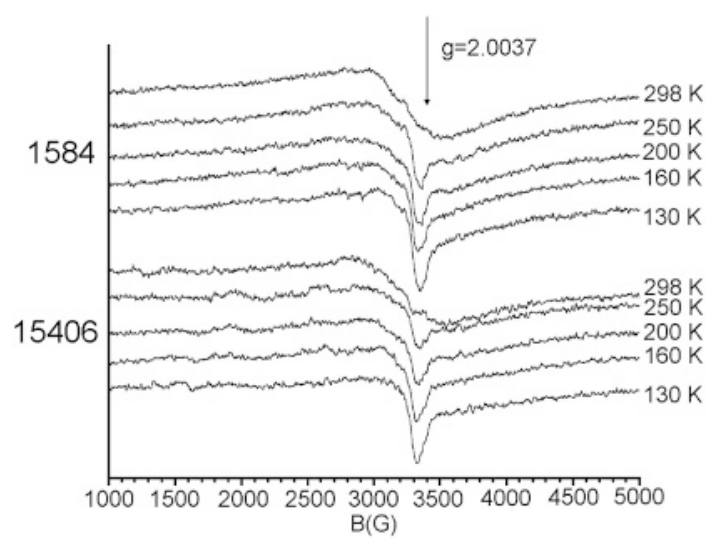

FIG. 6. EPR spectra of sample 1584 and 15406. The spectra were recorded at $9.5 \mathrm{GHz}$.

tuted by two adjacent $M_{1}$ tetrahedra. In samples where $\mathrm{Cu}^{2+}$ is more concentrated, dimers may result from a combination of $M_{1}$ positions (Fig. 10b). To explain the observed strong anisotropy of the hyperfine tensor component (Table 3 ), the geometry of bonding of the Sbridged $\mathrm{Cu}^{2+}$ pair has to be considered. By assuming the structural model for the dimer reported in Figure $10 \mathrm{~b}$, symmetry-adapted linear combinations of atomic orbitals (SALC) were taken into account. On this basis, the unpaired electrons of the two paramagnetic centers appear mainly delocalized in the plane defined by the $\mathrm{Cu}-\mathrm{S}-\mathrm{Cu}$ bridge, in which the contribution of $p$ and $d$ orbitals for $\mathrm{Cu}$ and that of $p$ for $\mathrm{S}$ are expected to predominate (Albright et al. 1985), being the plane where two components of the hyperfine tensor are the greatest. Starting from the best-fit D values, isotropic values

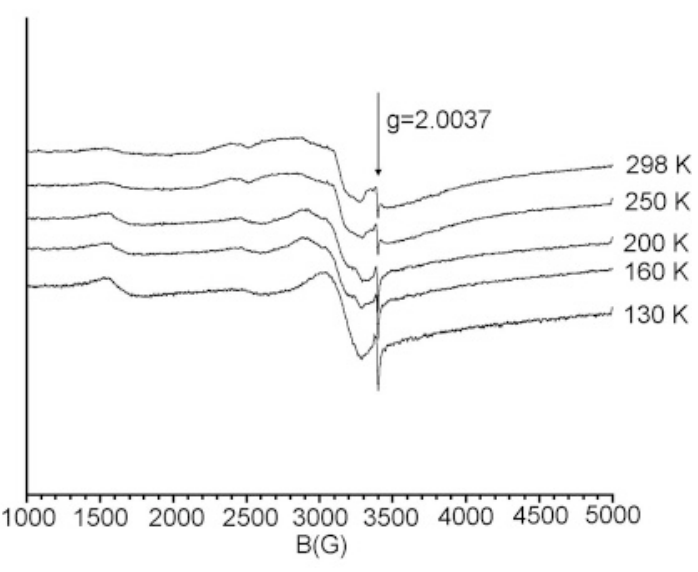

FIG. 7. EPR spectra of sample 1535. The spectra were recorded at $9.5 \mathrm{GHz}$.

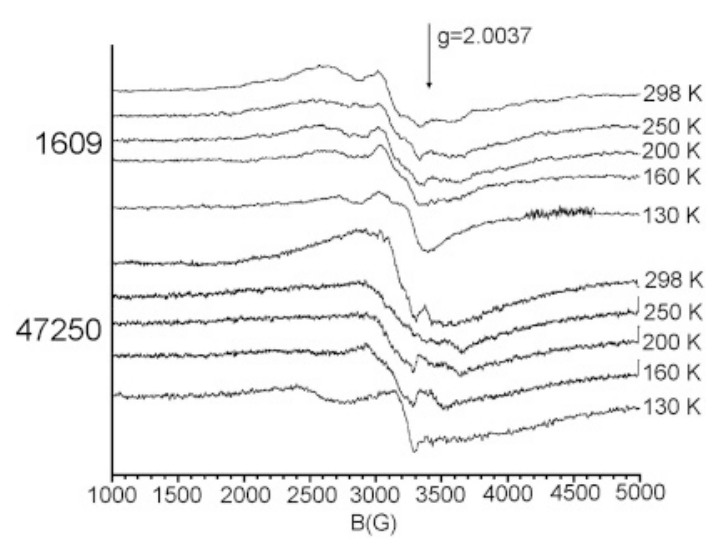

FIG. 8. EPR spectra of sample 1609 and 47250 . The spectra were recorded at $9.5 \mathrm{GHz}$.

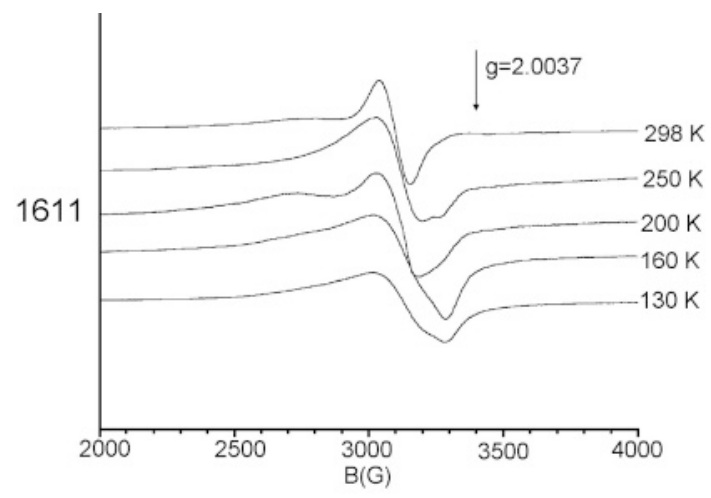

FIG. 9. EPR spectra of sample 1611. The spectra were recorded at $9.5 \mathrm{GHz}$. 

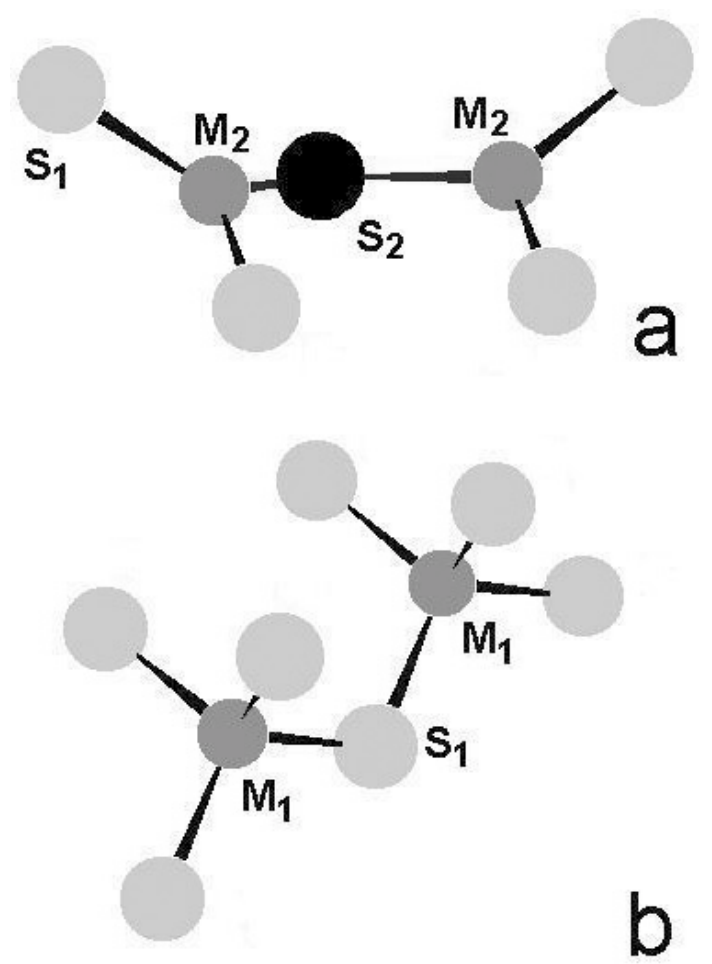

FIG. 10. Structure of dimers of $\mathrm{Cu}^{2+}$ in tetrahedrite: $M_{2}$ "cis" positions (a) and $M_{1}$ corner sharing tetrahedra (b). The symbols are defined in the text, except $S_{2}$ which denotes the additional sulphur atom.

of the exchange interaction constant $\mathrm{J}_{\text {iso }}$ were calculated at different temperatures applying the relation:

$$
J_{i s o}=\frac{8 D}{\frac{1}{4}\left(g_{3}-2\right)^{2}-\left(g_{\perp}-2\right)^{2}}
$$

where D is the ZFS parameter due to the anisotropic term of the interaction and $g_{\perp}=\left(g_{1}+g_{2}\right) / 2$. The reported $\mathrm{J}_{\text {iso }}$ values (Table 3) decrease with decreasing temperature. $\mathrm{J}_{\text {iso }}$ values for sample 1611 are significantly higher than the others, in agreement with the spectral evidence (more intense and narrow line).

\section{Magnetic data}

The magnetic data of the six selected samples are reported in Figures 11 and 12 as $\chi \mathrm{T}$ and $\chi^{-1}$ versus temperature, respectively. All samples exhibit a CurieWeiss-like behavior. Clear deviations from linearity (Fig. 12), predicted by a Curie-Weiss trend, are evident

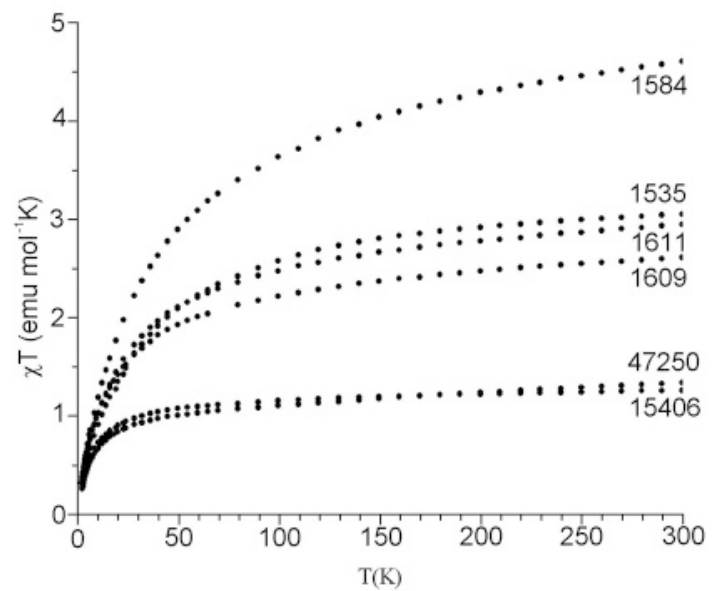

FIG. 11. $\chi \mathrm{T}$ versus $\mathrm{T}$ data of the investigated samples.

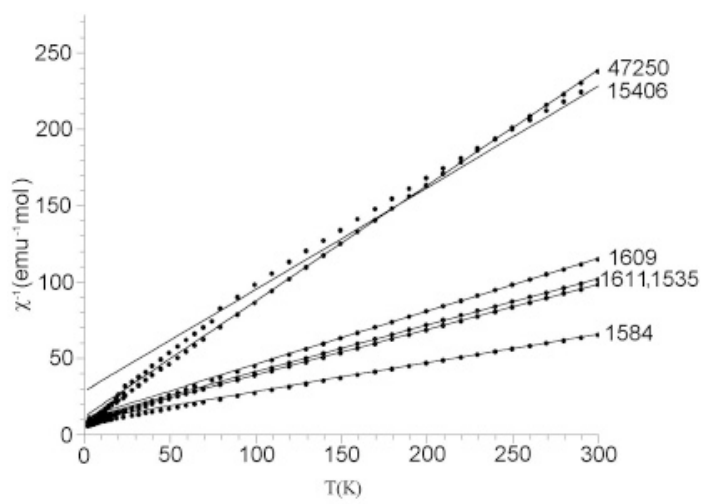

FIG. 12. $\chi^{-1}$ versus $\mathrm{T}$ data of the investigated samples (circles) and linear trends calculated on the basis of the refined magnetic constants (lines).

for all samples at about $20 \mathrm{~K}$, but sample 15406 shows the same effect at $\sim 70 \mathrm{~K}$. These deviations could be explained by the appearance of antiferromagnetic interactions.

According to Spałek et al. (1986), the trend of the inverse of $\chi^{-1}$ with T may be interpreted by means of the randomly diluted magnet approximation (Heisenberg high-temperature model), which implies a small fraction of paramagnetic centers $\left[\mathrm{Fe}^{2+}\right]$ statistically distributed in a diamagnetic framework composed by the monovalent $(\mathrm{Cu}, \mathrm{Ag})$ and divalent $(\mathrm{Zn}, \mathrm{Hg})$ diamagnetic cations. The values of the Curie $\left(\mathrm{C}_{x}\right)$ and Weiss constants $\left(\theta_{x}\right)$, both functions of the concentration $(x)$ of the paramagnetic center, have been refined from the relation: 


$$
\chi^{-1}=C_{x}^{-1}\left[T-\theta_{x}+\frac{\theta_{x}^{2}\left(1-\frac{z+2}{2}\right)}{T}\right]
$$

where $\mathrm{z}$ is the coordination number, which could be either 3 (Fe in $M_{2}$ site) or 4 (Fe in the $M_{1}$ site). Refined $\mathrm{C}_{x}$ and $\theta_{x}$ values, reported in Table 4, should have a linear dependence on $x$ (Spałek et al. 1986, Bernardini et al. 2000).

Whereas the least-squares refinement of $\mathrm{C}_{x}$ versus $x$ shows a good linear trend, $\theta_{x}$ and $x$ do not appear to be correlated. This effect may be due to the dependence of the Weiss constant on different parameters, related not only to the nature of the paramagnetic species, but also to their crystallographic distribution, the strength of the ligand field, and the interactions with minor substituents.

No strong variations in the least-squares parameters (slope, corresponding to the absolute Curie and Weiss constants, and intercept) are present as a function of $z$, as predicted from the equation used, in which $z$ affects only the second-order term of the $\theta_{x}$ expansion. On the other hand, $\mathrm{g}_{\text {eff }}$, which can be calculated from the absolute value of $\mathrm{C}$ reported in Table 5, is strongly dependent on the oxidation state and on the coordination of the paramagnetic ion (Boudreaux \& Mulay 1976). If $\mathrm{Fe}^{2+}$, with six electrons in the valence shell, occupies the $M_{2}$ planar trigonal site, the spin state can be only $\mathrm{S}$ $=0$ or $\mathrm{S}=1$, depending on the intensity of the ligand field (Albright et al. 1985); in the latter case, geff would be 3.81. Being Fe in tetrahedral $M_{1}, \mathrm{Fe}^{2+}$ is $\mathrm{S}=2$ and, therefore, $g_{\text {eff }}$ is 2.16 , a much more suitable value according to ligand field theory (Boudreaux \& Mulay 1976). The $\mathrm{g}_{\text {eff }}=1.82$ value for $M_{2}$ and 1.79 for $M_{1}$, which account for a $\mathrm{Fe}^{3+}$ with five unpaired electrons, $\mathrm{S}=5 / 2$, in both crystallographic $M_{1}$ and $M_{2}$ sites, is not allowed for Fe by filled orbital mixing due to spin-orbit

\begin{tabular}{|c|c|c|c|c|c|}
\hline \multirow[t]{2}{*}{ Sample } & \multirow[t]{2}{*}{$\mathrm{Fe}(a p f u)$} & \multicolumn{2}{|c|}{$\mathrm{C}_{\mathrm{x}}$} & \multicolumn{2}{|c|}{$\theta_{x}$} \\
\hline & & $z=3$ & $z=4$ & $z=3$ & $z=4$ \\
\hline 1611 & 0.87 & 3.37 & 3.40 & -47.30 & -53.97 \\
\hline 1584 & 1.41 & 5.50 & 5.25 & -68.87 & -55.08 \\
\hline 1609 & 0.68 & 2.95 & 3.00 & -42.46 & -51.78 \\
\hline 15406 & 0.37 & 1.64 & 1.54 & -80.19 & -59.28 \\
\hline 47250 & 0.36 & 1.32 & 1.33 & -16.88 & -17.79 \\
\hline 1535 & 1.03 & 3.43 & 3.47 & -39.39 & -44.59 \\
\hline$R^{2}$ & & 0.9814 & 0.9838 & -0.2477 & 0.3805 \\
\hline \multirow[t]{2}{*}{ Slope } & & 3.63 & 3.49 & -13.77 & -14.44 \\
\hline & & \pm 0.35 & \pm 0.33 & \pm 26.92 & \pm 17.22 \\
\hline \multirow[t]{2}{*}{ Intercept } & & 0.18 & 0.25 & -38.35 & -35.72 \\
\hline & & \pm 0.31 & \pm 0.28 & \pm 23.40 & \pm 14.97 \\
\hline
\end{tabular}

interaction (Drago 1977). In conclusion, in agreement with the MO calculations of Vaughan \& Burns (1972) and with the magnetic investigations on $\mathrm{Fe}^{2+}$ in similar coordination (Bernardini et al. 2000), Fe is surely divalent and occupies the tetrahedral site, thus explaining both the almost negligible orbital contribution to susceptibility and the presence of the antiferromagnetic interactions.

\section{Conclusions}

Of the 130 samples studied, all six samples investigated by EPR spectroscopy contain $\mathrm{Cu}^{2+}$ atoms. The presence and the relative amount of $\mathrm{Cu}^{2+}$ appear unrelated to the bulk composition of the tetrahedritetennantite solid solution; moreover, $\mathrm{Cu}^{2+}$ is present not only in samples with a sum of cations less than 12 , but also in those with a $\mathrm{Cu}+\mathrm{Ag}$ content higher than 10 $a p f u$, thus confirming the compositional data presented by Foit \& Ulbricht (2001).

The coordination polyhedron of $\mathrm{Cu}^{2+}$ is distorted, thus giving three g-values; according to Bernardini et al. (2000), the distortion of the tetrahedron should provide a similar anisotropy; moreover, the presence of directional interactions between pairs of $\mathrm{Cu}^{2+}$ indicates the presence of dimers in the more $\mathrm{Cu}^{2+}$-rich samples. The spectroscopic data point to the attribution of the $\mathrm{Cu}^{2+}$ species to the $M_{1}$ tetrahedron.

According to the susceptibility data, all $\mathrm{Fe}$ is divalent and occupies the tetrahedral $M_{1}$ sites; its distribution is completely ramdom. EPR measurements confirm this valence state and the presence of a very small amount of $\mathrm{Fe}^{3+}$ in sample 1535, which is characterized by a deficiency of the sum of metal cations.

The experimental data lead us to conclude that in natural tetrahedrite-tennantite solid solution, $\mathrm{Ag}$ substitutes for $\mathrm{Cu}$ in $\mathrm{M}_{2}$. If the sum of $\mathrm{Cu}+\mathrm{Ag}$ exceeds 6 $a p f u$, monovalent $\mathrm{Cu}$ occupies $M_{1}$ together with $\mathrm{Fe}^{2+}$ and the other divalent ( $\mathrm{Zn}, \mathrm{Hg}, \mathrm{Cd}, \mathrm{Mn}$ ) cations. Moreover, the substitution of divalent cations by $\mathrm{Cu}^{2+}$ is allowed in $M_{1}$, even if only small amounts of $\mathrm{Cu}^{2+}$ could be documented in the samples studied. The following crystal-chemical formula, therefore, may be proposed

\begin{tabular}{|c|c|c|c|c|}
\hline Cation & Spin state & Coordination & $\mathrm{CN}=3$ & $\mathrm{CN}=4$ \\
\hline $\begin{array}{l}\mathrm{Fe}^{2+} \\
\mathrm{Fe}^{2+} \\
\mathrm{Fe}^{2+} \\
\mathrm{Fe}^{3+}\end{array}$ & $\begin{array}{c}0 \\
1 \\
2 \\
5 / 2\end{array}$ & $\begin{array}{c}3 \\
3 \\
4 \\
3,4\end{array}$ & $\begin{array}{l}\overrightarrow{3.81(18)} \\
\dot{1} 82(4)\end{array}$ & $\begin{array}{r}\text { Diamagnetic } \\
\overline{2} .16(6) \\
1.79(4)\end{array}$ \\
\hline \multicolumn{3}{|c|}{ Absolute Curie constant } & $\begin{array}{r}3.63 \\
\pm 0.35\end{array}$ & $\begin{array}{r}3.49 \\
\pm 0.33\end{array}$ \\
\hline
\end{tabular}

$\mathrm{CN}$ : coordination number. 
for the tetrahedrite samples investigated: ${ }^{M 2}(\mathrm{Cu}, \mathrm{Ag})_{6}$ ${ }^{M 1}\left[\mathrm{Cu}^{+}, \mathrm{Zn}, \mathrm{Fe}, \mathrm{Hg}, \mathrm{Mn}, \mathrm{Cu}^{2+}\right]_{6} \mathrm{Sb}_{4} \mathrm{~S}_{13}$.

\section{ACKNOWLEDGEMENTS}

The authors express their warmest thanks to F.F. Foit, Jr., an anonymous referee, Associate Editor James Craig, and Robert F. Martin for their helpful suggestions and criticisms, which greatly improved the manuscript. Many thanks to A. Sabatini, who helped in numerical manipulations. This research was performed with the financial support of MURST, ex $40 \%$ funds to C. Cipriani and the Italian CNR.

\section{REFERENCES}

Abragam, A. \& Bleaney, B. (1970): Electron Paramagnetic Resonance of Transition Ions. Clarendon Press, Oxford, U.K.

Albright, T.A., Burdett, J.K. \& Whangbo, Myung-Hwan (1985): Orbital Interactions In Chemistry. John Wiley \& Sons, New York, N.Y.

Basu, K., Bortnikov, N.S., MookherJee, A., Mozgova, N.N., Sivstov, A.V., Tsepin, A.I. \& VRUblensKaJA, Z.V. (1984): Rare minerals from Rajpura-Dariba, Rajasthan, India. V. The first recorded occurrence of a manganoan fahlore. Neues Jahrb. Mineral., Abh. 149, 105-112.

Bernardini, G.P., Borrini, D., Caneschi, A., Di Benedetto, F., Gatteschi, D., Ristori, S. \& Romanelli, M. (2000): EPR and SQUID magnetometry study of $\mathrm{Cu}_{2} \mathrm{FeSnS}_{4}$ (stannite) and $\mathrm{Cu}_{2} \mathrm{ZnSnS}_{4}$ (kesterite). Phys. Chem. Minerals 27, 453-461.

Bente, K. (1987): Stabilization of Cu-Fe-Bi-Pb-Sn-Sulfides. Mineral. Petrol. 36, 205-217.

Boudreaux, E.A. \& Mulay, L.N. (1976): Theory and Application of Molecular Paramagnetism. John Wiley \& Sons, New York, N.Y.

Calas, G. (1988): Electron paramagnetic resonance. In Spectroscopic Methods in Mineralogy and Geology (F.C. Hawthorne, ed.). Rev. Mineral. 18, 513-571.

CARLIN, R.L. (1986): Magnetochemistry. Springer, Berlin, Germany.

Charlat, M. \& LÉVy, C. (1974): Substitutions multiples dans la série tennantite-tétraédrite. Bull. Soc. fr. Minéral. Cristallogr. 97, 241-250.

DobBE, R.T.M. (1992): Manganoan-cadmian tetrahedrite from the Tunaberg $\mathrm{Cu}-\mathrm{Co}$ deposit, Berslagen, central Sweden. Mineral. Mag. 56, 113-115.

Drago, R.S. (1977): Physical Methods in Inorganic Chemistry. Van Nostrand Reinhold, New York, N.Y.
FoIT, F.F., JR. \& Ulbricht, M.E. (2001): Compositional variation in mercurian tetrahedrite-tennantite from epithermal deposits of the Steens and Pueblo mountains, Harney County, Oregon. Can. Mineral. 39, 819-830.

JEANLOZ, R. \& JoHNSON, M.L. (1984): A note on the bonding, optical spectrum and composition of tetrahedrite. Phys. Chem. Minerals 11, 52-54.

JoHnson, M.L. \& JEANLOZ, R. (1983): A Brillouin-zone model for compositional variation in tetrahedrite. Am. Mineral. 68, 220-226.

Johnson, N.E., Craig, J.R. \& Rimstidt, J.D. (1986): Compositional trends in tetrahedrites. Can. Mineral. 24, 385-397.

$\&$ (1987): Effects of substitutions on the cell dimension of tetrahedrite. Can. Mineral. 25, 237-244.

KALBSKOPF, R. (1971): Die Koordination des Quecksilbers im Schwazit. Tschermaks Mineral. Petrogr. Mitt. 16, 173-175.

(1972): Strukturverfeinerung des Freibergits. Tschermaks Mineral. Petrog. Mitt. 18, 147-155.

Machatschki, F. (1928a): Formel und Kristallstruktur des Tetraedrites. Norsk Geol. Tidsskr. 10, 23.

(1928b): Präzisionsmessungen der Gitterkonstanten verschiedener Fahlerze. Formel und Struktur derselben. $Z$. Kristallogr. 68, 204-222.

MAKovicky, E., ForCher, K., LotTermoser, W. \& Amthauer, G. (1991): The role of $\mathrm{Fe}^{2+}$ and $\mathrm{Fe}^{3+}$ in synthetic $\mathrm{Fe}$ substituted tetrahedrite. Mineral. Petrol. 43, 73-81.

\& KARUP-MøLLER, S. (1994): Exploratory studies on substitution of minor elements in synthetic tetrahedrite. I. Substitution by $\mathrm{Fe}, \mathrm{Zn}, \mathrm{Co}, \mathrm{Ni}, \mathrm{Mn}, \mathrm{Cr}, \mathrm{V}$ and $\mathrm{Pb}$. Unitcell parameter changes on substitution and the structural role of $\mathrm{Cu}^{2+}$. Neues Jahrb. Mineral., Abh. 167, 89-123.

O'Connor, C.J. (1981): Magnetochemistry - advances in theory and experimentation. In Progress in Inorganic Chemistry 29 (S.J. Lippard, ed.). John Wiley and Sons, New York, N.Y. (203-283).

Palache, C., Berman, H. \& Frondel, C. (1944): Dana's System of Mineralogy 1 ( $7^{\text {th }}$ ed.). John Wiley and Sons, New York, N.Y.

PATTRICK, R.A.D. \& HALL, A.J. (1983): Silver substitution into synthetic zinc, cadmium and iron tetrahedrites. Mineral. Mag. 47, 441-451.

, VAN DER LAAN, G., VAUGHAN, D.J. \& HENDERSON, C.M.B. (1993): Oxidation state and electronic configuration determination of copper in tetrahedrite group minerals by L-edge X-ray absorption spectroscopy. Phys. Chem. Minerals 20, 395-401. 
Pauling, L. \& Neumann, E.W. (1934): The crystal structure of binnite, $(\mathrm{Cu}, \mathrm{Fe})_{12} \mathrm{As}_{4} \mathrm{~S}_{13}$ and the chemical composition and structure of minerals of the tetrahedrite group. $Z$. Kristallogr. 88, 54-62.

Peisach, J. \& Blumberg, W.D. (1974): Analysis of EPR copper: structural implications derived from the analysis of EPR spectra of natural and artificial Cu-proteins. Arch. Biochem. Biophys. 165, 691-708.

Peterson, R.C. \& Miller, I. (1986): Crystal structure and cation distribution in freibergite and tetrahedrite. Mineral. Mag. 50, 717-721.

Pfitzner, A., Evain, M. \& PetriceK, V. (1997): $\mathrm{Cu}_{12} \mathrm{Sb}_{4} \mathrm{~S}_{13}$ : a temperature-dependent structure investigation. Acta Crystallogr. B53, 337-345.

Skinner, B.J., Luce, F.D. \& Makovicky, E. (1972): Studies of the sulfosalts of copper. III. Phases and phase relations in the system Cu-Sb-S. Econ. Geol. 67, 924-938.

Spałek, J., Lewicki, A., Tarnawski, Z., Furdyna, J.K., Galazka, R.R. \& ObuszKo, Z. (1986): Magnetic suscep- tibility of semimagnetic semiconductors: the high-temperature regime and the role of superexchange. Phys. Rev. B 33, 3407-3418.

TATSUKA, K. \& Morimoto, N. (1977a): Tetrahedrite stability relations in the $\mathrm{Cu}-\mathrm{Sb}-\mathrm{S}$ system. Econ. Geol. 72, 258-270.

$\&$

(1977b): Tetrahedrite stability relations in the $\mathrm{Cu}-\mathrm{Fe}-\mathrm{Sb}-\mathrm{S}$ system. Am. Mineral. 62, 1101-1109.

Vaughan, D.J. \& BuRns, R.G. (1972): Mössbauer spectroscopy and bonding in sulphide minerals containing fourcoordinated iron. Proc. $24^{\text {th }}$ Int. Geol. Congress (Montreal) 14, 158-167.

\& PATTRICK, R.A.D. (1984): Mössbauer spectroscopy of iron-bearing tetrahedrites. NERC, Progress in Experimental Petrology 6, 86-90.

WUENSCH, B.J. (1964): The crystal structure of tetrahedrite, $\mathrm{Cu}_{12} \mathrm{Sb}_{4} \mathrm{~S}_{13}$. Z. Kristallogr. 119, 437-453.

Received September 18, 2001, revised manuscripts accepted February 22, 2002. 